Buletin Ilmiah Math. Stat. dan Terapannya (Bimaster)

Volume 08, No.3 (2019), hal 463-470.

\title{
MODEL MULTIPLE DECREMENT DALAM PENENTUAN PREMI ASURANSI JIWA
}

\author{
Dinda Lestari, Neva Satyahadewi, Hendra Perdana
}

\begin{abstract}
INTISARI
Asuransi jiwa adalah satu diantara produk asuransi yang umum dikenal, biasanya memiliki satu penyebab klaim yaitu kematian. Model produk asuransi jiwa dapat dimodifikasi dengan menambah penyebab-penyebab klaim lainnya, sehingga menjadi model asuransi dengan lebih dari satu penyebab klaim (multiple decrement). Model multiple decrement merupakan salah satu model aktuaria yang digunakan sebagai acuan dalam merancang suatu produk asuransi. Penelitian ini menggunakan 3 decrement sebagai penyebab terjadinya klaim yang terdiri dari kematian, cacat permanen dan mengundurkan diri. Data associated single decrement table menggunakan informasi dari Negara Canada Tahun 1968 yang diperoleh dari Software Table Manager 3.01. Studi kasus yang digunakan dalam penelitian ini yaitu seorang berusia 30 tahun mengikuti suatu asuransi jiwa multiple decrement berjangka selama 34 tahun. Diketahui bahwa nilai santunan ketika seorang tersebut mengalami kematian adalah Rp100.000.000, Rp50.000.000 bila mengalami kondisi cacat permanen, sedangkan Rp10.000.000 bila kondisi mengundurkan diri dari perusahaan. Suku bunga yang digunakan adalah 6\% berdasarkan BI Rate. Hasil perhitungan diperoleh premi tahunan untuk asuransi jiwa berjangka multiple decrement ini yaitu sebesar Rp317.946. Kemudian, jika tingkat suku bunga semakin tinggi maka nilai premi yang dibayarkan semakin murah. Hal ini dikarenakan tingkat suku bunga merupakan variabel dari fungsi diskonto, dimana semakin tinggi tingkat suku bunga, maka semakin kecil nilai dari fungsi diskonto. Premi akan semakin mahal jika usia nasabah ketika mengikuti asuransi semakin tinggi. Hal ini karena dipengaruhi peluang kematian seseorang yang semakin tinggi dengan bertambahnya usia.
\end{abstract}

Kata Kunci: multiple decrement, associated single decrement.

\section{PENDAHULUAN}

Risiko secara umum didefinisikan sebagai potensi terjadinya suatu peristiwa baik yang diperkirakan maupun yang tidak dapat diperkirakan dan dapat menimbulkan dampak bagi pencapaian tujuan. Hal ini dikarenakan apa yang akan terjadi di masa yang akan datang tidak dapat diketahui secara pasti, karena risiko merupakan suatu ketidakpastian maka akan menjadi suatu masalah penting[1]. Suatu usaha untuk mengurangi atau memperkecil risiko tetap dapat dilakukan dengan melakukan suatu pengendalian risiko dengan mengikuti program dari perusahaan asuransi.

Asuransi jiwa adalah satu diantara produk asuransi yang umum dikenal, dan biasanya memiliki satu penyebab klaim (single decrement) yaitu kematian. Model produk asuransi jiwa dapat dimodifikasi dengan menambah penyebab-penyebab klaim lainnya, sehingga menjadi model asuransi dengan lebih dari satu penyebab klaim (multiple decrement). Penambahan decrement menyebabkan perubahan dalam penentuan premi karena benefit yang diterima tertanggung juga berbeda. Pada model single decrement hanya melibatkan satu variabel random yaitu usia, sedangkan model multiple decrement melibatkan beberapa variabel random yang menyatakan penyebab[2].

Salah satu produk asuransi yang melibatkan model multiple decrement adalah asuransi jiwa dengan tambahan benefit kesehatan. Produk asuransi ini selain memberikan santunan terhadap kematian nasabah juga memberikan santunan jika nasabah jatuh sakit. Dari produk ini dapat dilihat bahwa terdapat dua decrement, yaitu kematian dan sakit. Perusahaan mengupayakan sistem pendanaan untuk memberikan jaminan hari tua pada karyawannya dalam bentuk produk dana pensiun. Dana pensiun ini diberikan tidak hanya karyawan berhenti pada usia pensiun, tetapi juga karyawan yang meninggal dalam tugas sebelum masa pensiun, karyawan yang mengalami kecelakaan dan cacat tetap dalam tugas sebelum masa pensiun, pensiun dini, serta pengunduran diri setelah masa kerja tertentu[3]. 
Penelitian ini membahas mengenai cara menentukan model multiple decrement dilanjutkan dengan membentuk tabel multiple decrement melalui tabel associated single decrement. Besar premi asuransi jiwa berjangka ditentukan melalui model multiple decrement yang difokuskan pada sebab klaim terjadi karena kematian, cacat permanen, dan mengundurkan diri. Data tabel associated decrement berasal dari negara Kanada yang diperoleh dari Software Table Manager 3.01. Perhitungan premi asuransi jiwa ini dimulai dengan menentukan usia nasabah, suku bunga, lama masa pertanggungan asuransi dan besar santunan (benefit) untuk tiap penyebab (decrement). Kemudian berdasarkan informasi tersebut dicari nilai anuitas jiwa, asuransi jiwa berjangka, serta premi asuransi jiwa berjangka menggunakan model multiple decrement.

\section{TINGKAT SUKU BUNGA}

Tingkat suku bunga (i) adalah rasio dari besar bunga yang diperoleh selama periode tertentu terhadap besarnya nilai pokok pada saat awal periode [3]. Nilai saat ini adalah investasi sebesar 1 yang akan terakumulasi menjadi $(i+1)$ pada akhir periode ke- $n$ [3]. Nilai saat ini juga bisa disebut dengan faktor diskonto yang dinotasikan dengan $v$, yaitu:

$$
v^{n}=\frac{1}{(i+1)^{n}}
$$

dimana:

$n=$ periode

$i=$ suku bunga

$v^{n}=$ faktor diskonto pada periode- $n$

\section{ASURANSI JIWA BERJANGKA}

Asuransi jiwa berjangka adalah asuransi dimana manfaat (benefit) dibayarkan kepada ahli waris bila si tertanggung (peserta asuransi) meninggal dalam jangka waktu tertentu. Berdasarkan waktu pembayaran manfaatnya, asuransi jiwa berjangka dibedakan atas 2 jenis, yaitu asuransi jiwa yang manfaatnya dibayarkan sesaat setelah kematian atau dengan kata lain digunakan waktu kontinu. Kemudian asuransi jiwa berjangka yang manfaatnya dibayarkan diakhir tahun periode kematian atau waktu diskret. Pada penelitian ini membahas asuransi jiwa berjangka waktu diskret.

Apabila didefinisikan $x$ sebagai usia seseorang saat mengikuti produk asuransi jiwa maka sisa usia dari $x$, yaitu $X-x$ dapat dinotasikan dengan $T_{x}$. Notasi inilah yang selanjutnya akan digunakan dalam pernyataan berikut ini.

$$
\begin{array}{r}
{ }_{t} p_{x}=\operatorname{Pr}\left[T_{x}>t\right], \quad \mathrm{t} \geq 0 \\
{ }_{t} q_{x}=1-{ }_{t} p_{x}
\end{array}
$$

Persamaan (2) dapat diartikan sebagai peluang untuk seseorang berusia $x$ akan tetap hidup hingga usia $x+t$. Persamaan (3) dapat diartikan sebagai peluang untuk seseorang berusia $x$ akan meninggal sebelum mencapai usia $x+t$.

Didefinisikan $T_{x}$ adalah sisa usia (future life time) dari seseorang yang mengikuti produk asuransi jiwa. Selanjutnya orang yang berasuransi disebut dengan tertanggung (insured) dan perusahaan asuransi disebut dengan penanggung (insurer). Dalam prakteknya, perusahaan asuransi jiwa mendapatkan informasi mengenai distribusi peluang $T_{x}$ dari tabel mortalita waktu diskret. Jika $K$ menunjukkan curtate-future-lifetime dari tertanggung (insured) pada polis, maka distribusi peluang $K_{x}$ adalah suatu fungsi dari $T_{x}$. Fungsi manfaat (benefit), $b_{k+1}$ yaitu jumlah pembayaran manfaat dimana indeks $k+1$ menyatakan sisa usia dari nasabah. Fungsi diskonto $v_{k+1}$, yaitu faktor diskonto 
yang ditetapkan untuk periode dari waktu pengembalian pembayaran sampai waktu diterbitkannya polis ketika tertanggung mempunyai sisa usia masa depan $k$, yaitu ketika tertanggung meninggal pada tahun $k+1$ dari asuransi.

Nilai waktu sekarang (present value) pada saat polis diterbitkan dari pembayaran manfaat asuransi dinotasikan dengan, $z_{k+1}$, yaitu:

$$
z_{k+1}=\left(b_{k+1}\right)\left(v_{k+1}\right)
$$

Asuransi jiwa berjangka $n$ tahun memberikan manfaat sebesar satu satuan pada akhir tahun kematian, diberikan oleh:

$$
\begin{array}{ll}
b_{k+1}= \begin{cases}1 & , k=0,1,2, \ldots, n-1 \\
0 & , k=n, n+1, \ldots\end{cases} \\
v_{k+1}=\left\{\begin{array}{cc}
v^{k+1} & , k=0,1,2, \ldots, n-1 \\
0 & , k=n, n+1, \ldots
\end{array}\right.
\end{array}
$$

Nilai sekarang aktuaria (actuarial present value) untuk asuransi jiwa berjangka satu penyebab yaitu (kematian) diberikan sebagai berikut:

$$
A_{x: n}^{1}=E[Z]=\sum_{k=0}^{n-1}\left(v^{k+1}\right)\left({ }_{k} p_{x}\right)\left(q_{x+k}\right)
$$

\section{MODEL MULTIPLE DECREMENT}

Model multiple decrement merupakan salah satu model aktuaria yang dapat digunakan dalam merancang suatu produk asuransi. Model multiple decrement bermakna terdapat lebih dari satu decrement. Pada model single decrement menggunakan satu variabel random kontinu yaitu variabel sisa usia. Pada model multiple decrement terdapat variabel random lain selain $T_{x}$ yang di notasikan dengan $J$ yaitu variabel random diskrit penyebab decrement. Ilustrasi model multiple decrement dengan 3 decrement dapat dilihat pada Gambar 1.

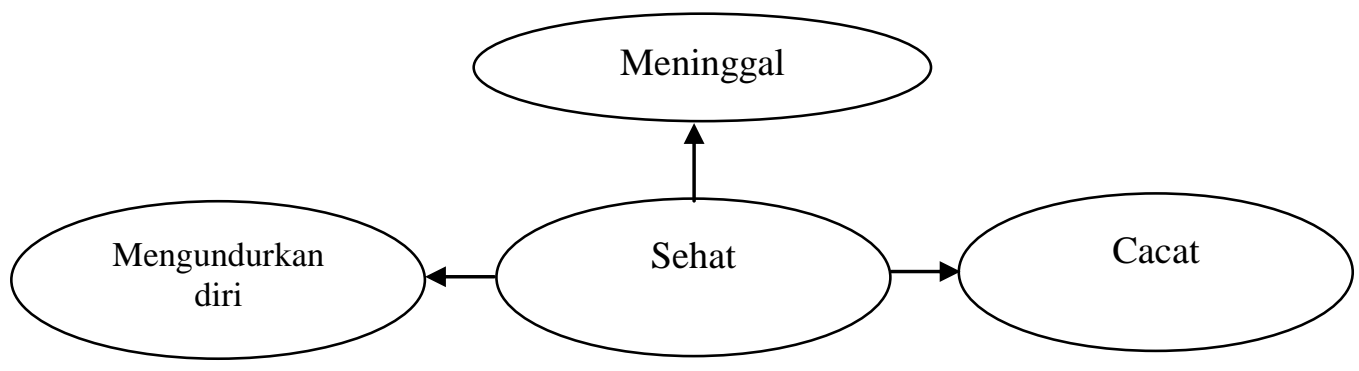

Gambar 1 Contoh model multiple decrement dengan 3 penyebab

\section{ASURANSI JIWA BERJANGKA MULTIPLE DECREMENT}

Model beberapa penyebab kegagalan (multiple decrement) kontinu dapat dikembangkan mulai dari pendefinisian fungsi kepadatan peluang bersama (joint $p d f$ ) antara variabel random $T_{x}$ untuk suatu nilai $t$ dan variabel random $J$ untuk suatu nilai $j$. Joint $p d f$ ini dinotasikan dengan $f_{T_{x}, J}(t, j)$, di mana berlaku: $\int_{0}^{\infty} \sum_{j=1}^{m} f_{T_{x}, J}(t, j)=1$.

Peluang bahwa seseorang yang saat ini berusia $x$ akan mengalami kegagalan dikarenakan penyebab $j$ selambatnya $t$ tahun dari sekarang (selambatnya saat berusia $x+t$ ) dinotasikan dengan ${ }_{t} q_{x}^{(j)}$. Adapun hubungan ${ }_{t} q_{x}^{(j)}$ dengan $f_{T_{x}, J}(t, j)$ adalah sebagai berikut: 


$$
{ }_{t} q_{x}^{(j)}=\int_{0}^{t} f_{T_{x}, J}(s, j) d s=\operatorname{Pr}\left\{\left(0<T_{x} \leq t\right) \cap(J=j)\right\}
$$

Selanjutnya, akan dilakukan peninjauan terhadap semua penyebab kegagalan. Bila kedua ruas dari Persamaan (7) ini dijumlahkan untuk semua nilai $j$ yang mungkin (dari 1 hingga $m$ ), maka diperoleh

$$
\sum_{j=1}^{m}{ }_{t} q_{x}^{(j)}=\sum_{j=1}^{m} \operatorname{Pr}\left\{\left(0<T_{x} \leq t\right) \cap(J=j)\right\}
$$

Ruas kanan dari Persamaan (8) menyatakan peluang bahwa seseorang yang saat ini berusia $x$ akan mengalami kegagalan dikarenakan penyebab maupun yang mungkin (antara penyebab 1 hingga penyebab $m$ ) selambatnya pada usia $x+t$ tahun. Artinya, pada ruas kanan persamaan di atas, semua nilai yang mungkin bagi variabel random $J$ telah ditinjau, sehingga Persamaan (8) dapat dinyatakan sebagai:

$$
\sum_{j=1}^{m}{ }_{t} q_{x}^{(j)}=\operatorname{Pr}\left(0<T_{x} \leq t\right)
$$

Persamaan (9) dapat dinotasikan sebagai berikut

$$
{ }_{t} q_{x}^{(\tau)}=\sum_{j=1}^{m}{ }_{t} q_{x}^{(j)}
$$

Peluang bahwa seseorang yang saat ini berusia $x$ akan bertahan dari semua penyebab kegagalan (dari penyebab 1 hingga penyebab $m$ ) setidaknya hingga usia $x+t$ tahun dinotasikan sebagai ${ }_{t} p_{x}^{(\tau)}$, di mana:

$$
{ }_{t} p_{x}^{(\tau)}=1-{ }_{t} q_{x}^{(\tau)}
$$

Joint pdf dari variabel random $K_{x}$ dan $\mathrm{J}$ untuk nilai $K_{x}=k$ dan $J=j$ dinotasikan dengan $f_{K_{x}, J}(k, j)$, dimana:

$$
f_{K_{x}, J}(k, j)=\operatorname{Pr}\left\{\left(K_{x}=k\right) \cap(J=j)\right\}
$$

Persamaan (12) menyatakan peluang bahwa seseorang yang saat ini berusia $x$ tahun telah menjalani $k$ tahun secara penuh sebelum mengalami kegagalan yang dikarenakan penyebab $j$. Artinya, orang tersebut mengalami kegagalan ketika berusia antara $(x+k)$ dan $(x+k+1)$.

Berdasarkan hal ini, diperoleh hubungan antara nilai $f_{K_{x}, J}(k, j)$ dengan nilai $f_{T_{x}, J}(k, j)$ sebagai berikut

$$
\operatorname{Pr}\left\{\left(K_{X}=k\right) \cap(J=j)\right\}={ }_{k} p_{x}^{(\tau)} q_{x+k}^{(j)}
$$

Artinya, peluang bahwa seseorang yang saat ini berusia $x$ akan menjalani $k$ tahun sebelum akhirnya mengalami kegagalan dikarenakan penyebab $j$. Kemudian, akan ditentukan peluang terjadinya kegagalan pada interval waktu $(k, k+1)$ yang dikarenakan oleh semua penyebab. Peluang terjadinya kegagalan pada interval waktu $(k, k+1)$ yang dikarenakan oleh semua penyebab dapat diperoleh dengan menjumlahkan untuk seluruh nilai $j$, yakni:

$$
\begin{aligned}
\operatorname{Pr}\left(K_{X}=k\right) & =\sum_{j=1}^{m} f_{K_{x}, j}(k, j) \\
& =\left({ }_{k} p_{x}^{(\tau)}\right)\left(q_{x+k}^{(\tau)}\right)
\end{aligned}
$$

Nilai sekarang aktuaria (actuarial present value) untuk asuransi jiwa berjangka model multiple decrement ini diberikan sebagai berikut:

$$
A_{x: n}^{1^{*}}=\sum_{k=0}^{n-1}\left(v^{k+1}\right)\left({ }_{k} p_{x}^{(\tau)}\right)\left(q_{x+k}^{(j)}\right)
$$


Peluang bahwa seseorang yang saat ini berusia $x$ akan bertahan dari semua penyebab kegagalan (dari penyebab 1 hingga penyebab $m$ ) setidaknya hingga usia $x+k$ tahun dinotasikan sebagai ${ }_{k} p_{x}^{(\tau)}$. Peluang bahwa seseorang yang saat ini berusia $x+k$ akan mengalami kegagalan dikarenakan penyebab $j$ selambatnya 1 tahun dari sekarang dinotasikan dengan $q_{x+k}^{(j)}$.

\section{ANUITAS JIWA MODEL MULTIPLE DECREMENT}

Anuitas adalah suatu deretan pembayaran, dalam jumlah yang sama untuk suatu jangka waktu dan lama tertentu secara berkelanjutan. Anuitas jiwa adalah anuitas yang setiap pembayarannya hanya dilakukan jika pemegang polis masih hidup atau dalam jangka waktu yang ditentukan sesuai jenis kontrak asuransinya. Teori anuitas memegang peran penting dalam aktuaria, karena pembayaran premi pada perusahaan asuransi jiwa oleh pemegang polis mempunyai bentuk anuitas jiwa pemegang polis kepada perusahaan [4].

Anuitas jiwa diskret adalah anuitas jiwa yang dibayar secara berkala tiap tahun polis. Berdasarkan jenisnya anuitas jiwa diskret terdiri dari anuitas jiwa diskret awal (annuity due) dan anuitas jiwa diskret akhir (annuity immediate). Anuitas jiwa diskret awal adalah anuitas jiwa yang dibayarkan pada awal tahun polis. Anuitas jiwa diskret akhir adalah anuitas jiwa yang dibayarkan pada akhir tahun polis.

Rumus anuitas berjangka awal dengan jangka waktu $n$ tahun, yaitu [5]:

$$
\ddot{a}_{x: n}=\sum_{k=0}^{n-1} v^{k}{ }_{k} p_{x}
$$

Pada penelitian ini anuitas jiwa yang digunakan yaitu anuitas berjangka awal dengan jangka waktu $n$ tahun untuk model multiple decrement, yaitu:

$$
\ddot{a}^{*}{ }_{x: n}=\sum_{k=0}^{n-1} v_{k}^{k} p_{x}^{(\tau)}
$$

\section{PREMI ASURANSI JIWA BERJANGKA MODEL MULTIPLE DECREMENT DISKRET}

Premi adalah sejumlah uang yang wajib dibayarkan oleh pemegang polis kepada perusahaan asuransi dengan cara yang telah ditentukan dan sekaligus menjadi syarat diperolehnya perlindungan asuransi. Dalam asuransi jiwa penentuan tarif menjadi hal yang harus diperhatikan, karena besarnya premi yang akan diterima ditentukan dari besarnya tarif premi [6]. Rumus premi tunggal bersih untuk asuransi jiwa berjangka $n$-tahun model multiple decrement, yaitu:

$$
P\left(A_{x: n}^{1^{*}}\right)=\sum_{j=1}^{m}\left(\sum_{k=0}^{n-1} B^{(j)} v_{k}^{k+1} p_{x}^{(\tau)} q_{x+k}^{(j)}\right)
$$

Rumus premi tahunan untuk asuransi jiwa berjangka $n$-tahun multiple decrement, yaitu:

$$
P *\left(A_{x: n}^{1^{*}}\right)=\frac{P\left(A_{x: n}^{1^{*}}\right)}{\ddot{a}_{x: n}^{*}}
$$

\section{STUDI KASUS}

Pada penelitian ini akan diberikan studi kasus sebagai simulasi perhitungan premi asuransi jiwa berjangka untuk produk asuransi jiwa multiple decrement dengan program yang akan digunakan adalah Microsoft Excel. Contoh kasus, seorang berusia 30 tahun mengikuti suatu asuransi jiwa multiple decrement berjangka selama 34 tahun. Diketahui bahwa nilai santunan ketika seorang tersebut mengalami kematian adalah Rp100.000.000, Rp50.000.000 bila mengalami kondisi cacat permanen, sedangkan Rp10.000.000 bila kondisi mengundurkan diri dari perusahaan. Suku bunga yang digunakan adalah $6 \%$. 
Pada pembentukan tabel beberapa penyebab kegagalan (multiple decrement table), akan sangat baik apabila data-data yang dimiliki dapat digunakan untuk langsung mengestimasi $q_{x}^{(\tau)}$ Namun biasanya hal ini sulit dilakukan, sehingga mengatasi hal ini dengan menggunakan data pada tabel penyebab kegagalan tunggal terkait (associated single decrement table).

Berdasarkan studi kasus diatas, diperoleh informasi sebagai berikut:

1. Usia nasabah, $x=30$ tahun;

2. Lama masa pertanggungan asuransi, $n=34$ tahun;

3. Santunan karena sebab kematian, $B_{t}^{(1)}=R p 100.000 .000$;

4. Santunan karena sebab cacat permanen, $B_{t}^{(2)}=R p 50.000 .000$;

5. Santunan karena sebab mengundurkan diri, $B_{t}^{(3)}=R p 10.000 .000$;

6. Tingkat suku bunga, $i=6 \%$

Adapun dalam hal ini associated single decrement table yang digunakan yaitu:

1. Usia penelitian yang digunakan 18-64 tahun, $x$;

2. Kegagalan yang disebabkan kematian (death), $q_{x}^{(1)}$;

3. Kegagalan yang disebabkan cacat permanen (permanent disability), $q_{x}^{(2)}$;

4. Kegagalan yang disebabkan mengundurkan diri dari perusahaan (resign), $q_{x}^{(3)}$.

Tabel 1 Penentuan Nilai $q_{x}^{(\tau)}$ dan $p_{x}^{(\tau)}$

\begin{tabular}{cccccc}
\hline Usia $(x)$ & $q_{x}^{(1)}$ & $q_{x}^{(2)}$ & $q_{x}^{(3)}$ & $q_{x}^{(\tau)}$ & $p_{x}^{(\tau)}$ \\
\hline 18 & 0,00128 & 0,00007 & 0,00006 & 0,00141 & 0,99859 \\
19 & 0,00120 & 0,00008 & 0,00004 & 0,00132 & 0,99868 \\
20 & 0,00113 & 0,00009 & 0,00003 & 0,00125 & 0,99875 \\
$\vdots$ & $\vdots$ & $\vdots$ & $\vdots$ & $\vdots$ & $\vdots$ \\
62 & 0,01772 & 0,00701 & 0,01536 & 0,03959 & 0,96041 \\
63 & 0,01949 & 0,00793 & 0,01739 & 0,04418 & 0,95582 \\
64 & 0,02137 & 0,00892 & 0,01956 & 0,04907 & 0,95093 \\
\hline
\end{tabular}

Nilai premi asuransi tunggal diperoleh menggunakan Persamaan (4), yaitu:

$$
P^{*}\left(A_{30: 34}\right)=\sum_{j=1}^{3}\left(\sum_{k=0}^{34-1} B^{(j)} v_{k}^{k+1} p_{30}^{(\tau)} q_{30+k}^{(j)}\right)=R p 4.795 .910
$$

Sehingga premi tunggal untuk asuransi jiwa berjangka seorang berusia 30 tahun jangka waktu asuransi selama 34 tahun, dengan beberapa kemungkinan penyebab kegagalan yaitu sebesar $R p 4.795 .910$.

Perhitungan premi tahunan dalam hal ini membutuhkan nilai anuitas, dimana anuitas yang digunakan adalah anuitas awal. Berdasarkan Persamaan (3) diperoleh nilai anuitas, yaitu:

$$
\ddot{a}_{30: 34}=\sum_{k=0}^{n-1} v_{k}^{k} p_{x}^{(\tau)}=15,084
$$

Sehingga premi tahunan untuk asuransi jiwa berjangka seorang berusia 30 tahun jangka waktu asuransi selama 34 tahun, yaitu:

$$
\frac{P^{*}\left(A_{30: 34}^{1}\right)}{\ddot{a}_{30: 34}}=\frac{4.795 .910}{15,084}=R p 317.946
$$

Premi tahunan untuk asuransi jiwa berjangka seorang berusia 30 tahun jangka waktu asuransi selama 34 tahun, yaitu sebesar $R p 317.946$. 


\section{Perhitungan Premi Asuransi dengan Suku Bunga Bervariasi}

Pada Tabel 2 menunjukkan perbandingan nilai premi asuransi jiwa berjangka seorang berusia 30 tahun dengan lama masa pertanggungan asuransi selama 34 tahun, menggunakan tingkat suku bunga bervariasi. Tingkat suku bunga yang digunakan yaitu 1\%-6\%. Semakin besar tingkat suku bunga, maka nilai premi asuransi juga akan semakin murah. Hal ini karena tingkat suku bunga merupakan variabel dari fungsi diskonto. Semakin besar tingkat suku bunga, maka semakin kecil nilai dari fungsi diskonto, sehingga nilai premi asuransi yang diperoleh juga akan semakin murah.

Tabel 2 Premi asuransi dengan suku bunga 1\% s.d 6\%

\begin{tabular}{crr}
\hline Suku Bunga & Premi Tunggal & Premi Tahunan \\
\hline $1 \%$ & 13.908 .323 & 491.989 \\
$2 \%$ & 11.030 .405 & 450.803 \\
$3 \%$ & 8.829 .599 & 412.815 \\
$4 \%$ & 7.135 .128 & 378.049 \\
$5 \%$ & 5.821 .475 & 346.461 \\
$6 \%$ & 4.795 .910 & 317.946 \\
\hline
\end{tabular}

\section{Premi Asuransi dengan Usia Bervariasi}

Pada Tabel 3 menunjukkan perbandingan nilai premi asuransi jiwa dengan lama masa pertanggungan asuransi selama 34 tahun dan usia yang bervariasi. Usia yang digunakan yaitu 20 tahun, 22 tahun, 24 tahun, 26 tahun, 28 tahun dan 30 tahun. Tingkat suku bunga yang digunakan yaitu $6 \%$. Semakin besar usia nasabah, maka nilai premi asuransi juga akan semakin mahal. Hal ini karena dipengaruhi peluang kematian seseorang yang semakin tinggi dengan bertambahnya usia.

Tabel 3 Premi asuransi dengan usia bervariasi

\begin{tabular}{lrr}
\hline Usia $(\boldsymbol{x})$ & Premi Tunggal & Premi Tahunan \\
\hline 20 tahun & 2.371 .183 & 157.198 \\
22 tahun & 2.660 .190 & 176.358 \\
24 tahun & 3.042 .111 & 201.677 \\
26 tahun & 3.524 .431 & 233.653 \\
28 tahun & 4.109 .910 & 272.467 \\
30 tahun & 4.795 .910 & 317.946 \\
\hline
\end{tabular}

\section{PENUTUP}

Pada penelitian ini digunakan 3 decrement sebagai penyebab terjadinya klaim terdiri dari kematian (death), cacat permanen (permanent disability) dan mengundurkan diri (resign). Data associated single decrement table menggunakan informasi dari Negara Canada Tahun 1968 yang diperoleh dari Software Table Manager 3.01. Perhitungan besar premi menggunakan model multiple decrement dimana pada studi kasus seorang berusia 30 tahun mengikuti suatu asuransi jiwa berjangka dengan masa pertanggungan selama 34 tahun. Diketahui bahwa nilai santunan ketika seorang tersebut mengalami kematian adalah $R p 100.000 .000, R p 50.000 .000$ bila mengalami kondisi cacat permanen, sedangkan Rp10.000.000 bila kondisi mengundurkan diri. Premi yang harus dibayar tertanggung sebesar $R p 4.795 .910$ jika suku bunga yang digunakan adalah 6\%. Besaran premi yang dibayarkan dapat semakin murah jika tingkat suku bunga semakin tinggi. Hal ini dikarenakan tingkat suku bunga merupakan variabel dari fungsi diskonto, dimana semakin tinggi tingkat suku bunga, maka semakin kecil nilai dari fungsi diskonto. 


\section{DAFTAR PUSTAKA}

[1]. McNeil AJ. Extreme Value Theory for Risk Managers. Departement Mathematik, ETH Zentrum, CH-8092 Zurich; 1999.

[2]. Hartawan, I G N. Model Multiple Decrement dan Aplikasinya. Prosiding: UNDIKSHA; 2014.

[3]. Effendie, A.R. Matematika Aktuaria. Universitas Terbuka. Jakarta; 2013.

[4]. Futami T. Matematika Asuransi Jiwa Bagian I. Tokyo: Incorporated Foundation Oriental Life Insurance Cultural Development Center; 1993.

[5]. Achdijad D. Prinsip-Prinsip Aktuaria pada Asuransi Jiwa. Jakarta: Gunadarm; 1990.

[6]. Bowers, N. L., Geerber, H. U., Hickman, J. C., Jones, D. A., \& Nesbitt, C. J. Actuarial Mathematics. Schaumhurg: Society Of Actuaries; 1997.

[7]. Salim A. Abbas. Dasar-Dasar Asuransi Ed ke-2. Rajawali Pers. Jakarta; 1991.

DINDA LESTARI

NEVA SATYAHADEWI

HENDRA PERDANA
: Jurusan Matematika FMIPA UNTAN, Pontianak dindalestariid@student.untan.ac.id

: Jurusan Matematika FMIPA UNTAN, Pontianak neva.satya@math.untan.ac.id

: Jurusan Matematika FMIPA UNTAN, Pontianak hendra.perdana@math.untan.ac.id 